\title{
The Community-Based Poverty Reduction Projects (CPRP), Poverty Reduction and Development in Yobe State Nigeria: A Pilot Study Report
}

\author{
Hassana Ibrahim Waziri \\ Department of Political Science \\ University of Maiduguri, Maiduguri Nigeria \\ Chukwuemeka Jaja Nwanegbo PhD \\ Department of Political Science \\ Federal University Wukari, Wukari Nigeria
}

Received: April 9, 2018 Accepted: June 13, 2018 Online published: June 25, 2018

doi:10.5296/jpag.v8i2.13317～URL: https://doi.org/10.5296/jpag.v8i2.13317

\begin{abstract}
This paper examines the impact of the Community-Based Poverty Reduction Project (CPRP) in alleviating poverty in selected benefiting communities in Yobe State. Purposive and simple random sampling was used to select the area of study and respondents. Questionnaires, Focus Group Discussion and Key Informants Interview were also used to collect data. The data was presented by the use of simple percentage and frequency tables, graphs and charts. Data was analysed through the use of ANOVA. The discourse, guided by the Basic Needs Theory found out that even though the concept for which the CPRP was adopted has been achieved, e.g. community participation and provision of 838 micro-projects in the whole of Yobe State, the micro-projects or basic needs infrastructure implemented are not adequate and wide-spread enough to reduce poverty in concrete terms. It however reduced the stress of people in accessing some basic needs e.g. water supply in some communities. The paper recommends that to effectively achieve poverty reduction, there should be sustained commitment of funding and maintenance of projects by respective stakeholders for holistic and widespread approach to poverty reduction in Yobe State. Nonetheless, this paper maintains that the CPRP poverty reduction intervention is a viable tool for the provision of basic needs infrastructure in rural communities to set the path for development of Yobe State.
\end{abstract}

Keywords: CPRP, poverty reduction, development, community development, basic needs 


\section{Introduction}

The phenomenon of poverty in the globe and indeed Nigeria has continued to be under examination in bid to find lasting solutions to it. Poverty in Nigeria is worst experienced in the North East and with the recent violent and destructive activities of the Boko Haram insurgency have further rendered poverty in this area on a precarious scale. Compared with the South East, the rate of poverty in the North East as reported by Kpakol (2006) clearly showed the South East region with a poverty rate of 26.7 percent, while the North-East had 72.2 percent when the National poverty average stood at 54.4 percent.

Before the start of the Community-Based Poverty Reduction Projects (CPRP) in 2001 Yobe State had a poverty rate of 71.9 percent in 1999 (Pate and Garba, 2010). The indicator to this is that Yobe State has not achieved an appreciable level of development since its creation in 1991. This is better understood when placed on the scale of measuring development as contained in the contending dominant literature on development (see Nnoli, 1986; Rodney, 1972, etc). Physically, it can also be seen in the problems of inadequate viable economic and commercial activities, basic social infrastructure, especially education, health, transport etc., despite its endowment with diverse economic potentials like mineral deposits, agriculture and livestock production.

This glaring disparity has remained an issue of immense concern to Yobe State government, policy makers, Non-governmental organizations and concerned individuals who have been trying to evolve programmes and policies on how to reduce poverty in the State. Indication of this is that Yobe State has been involved in the various poverty reduction measures in the past by the Federal Government, yet, appreciable progress were not recorded. Indeed, most of those past poverty reduction measures have been adjudged by many studies to have failed to reduce poverty especially among rural communities. This has been attributed many reasons including essentially the supply-driven, top bottom approach to these poverty reduction programmes. Those failures left the state at precarious poverty state counting it among the six (6) poorest states from the six geopolitical regions in Nigeria and qualifying it for selection for the pilot programme of the Community-Based Poverty Reduction Programme (CPRP) at its introduction in 2001.

CPRP is a bottom up, demand-driven poverty reduction intervention supported by the World Bank, Africa Development Bank and Federal Government in partnership with the benefitting poor communities. As a major shift from the supply-driven, top-down to demand-driven, bottom-up approach to rural development and poverty reduction measures CPRP was designed at its pilot stage to test how it would benefit the selected communities for development initiatives and poverty reduction, and requires the active involvement of the benefiting Community members in all the intervention process. This paper assesses the benefit of the CPRP to the benefitting communities vis a vis its impact towards poverty reduction.

The main objective of the study was to assess the impact of the Community-based Poverty Reduction Project (CPRP) as a strategy to reduce poverty through the execution of micro-projects in the selected rural communities. Specifically, the study assessed the projects 
executed with the benefits derived by the selected benefiting communities, by identifying the projects executed what benefits were derived by the selected benefiting communities. This study was restricted to the assessment of the Community-based Poverty Reduction Project in three local government areas of Fika, Damaturu and Yunusari spread along the three senatorial districts of Yobe State between 2002 and 2009.

\section{Literature Review: Poverty, Poverty Reduction and Development}

Defining poverty is faced with the challenge of general acceptability as many other terms in social science. In fact, defining poverty remains problematic and the debate relating to what constitutes it, how it is measured and how it is to be tackled, rages on. That bothers on the issue of the universality of the definition. Looking at it in a simple form, some have generally viewed poverty as a state of being poor. There are several identified frameworks which may be useful for understanding and measuring poverty such as material poverty, money-metric measurement approaches and multidimensional approaches, etc (Hulme, Moore and Shepherd, 2001). Scholars who adopt the material and physiological approaches view poverty as a lack of income, expenditure or consumption. However, the view about poverty has been broadened based somewhat on the increased credence given to the views of poverty by the poor themselves. As Bevan and Joireman (1997) argue, 'while poverty everywhere involves people experiencing very real material and other deprivations, the concept of poverty is used to cover a wide-ranging set of interrelated life-chances which vary and are valued differently in the diverse cultures and sub-cultures of the world'. This is based on the belief that the poor are likely to be poor in several ways, not only in terms of income.

The notion of what constitutes 'basic needs' has been expanded to encompass not only food, water, shelter, and clothing, but also access to other assets such as education, basic healthcare, participation in the political process, security and dignity. The World Bank (2000) described poverty in terms of material deprivation, low levels of education and health, exposure to vulnerability and risk, and 'voicelessness' and 'powerlessness'. Multi-dimensional approaches capture the full range of deprivations that constitute poverty, and may empower and give 'voice' to the poor, but lack the precision and comparability of income/consumption measures.

Poverty could be explained as lack, inadequacy, deficiency and inability of one to optimally surmount basic daily needs. According to Aboyade (1976), poverty is a state of inadequate command over, or inadequate access to, resources to satisfy wants which are considered normal by the value system of a given society. World Bank Development Report (2000) explained poverty as an unaccepted deprivation in human well-being which comprise both physiological deprivation in human includes, inadequate nutrition, health, education, shelter and social deprivation which includes risk, lack of autonomy, lack of self-respect and powerlessness. In Sen (1999)'s views poverty can be seen from the perspective of capability deprivation. He argued that poverty must be seen as the deprivation of basic capabilities rather than merely as lowness of income, which is the standard criterion of identification of poverty. His claims on capability approach to poverty rely on the following assumptions; 
(1) Poverty can be sensibly identified in terms of capability deprivation; the approach concentrates on deprivations that are intrinsically important (unlike low income, which is only instrumentally significant)

(2) There are influences on capability deprivation and thus on real poverty- other than lowness of income (income is not only instrument of generating capabilities).

(3) The instrumental relation between low and capability is variable between different communities and even between different families and individuals (the impact of income on capabilities is contingent and conditional).

Based on this, it is imperative to note that low income may not unilaterally cause poverty. For Obadan (1997); the main factors that cause poverty include among others: inadequate access to employment opportunities; inadequate physical assets such as land and capital and minimal access by the poor to credit even on a small scale; inadequate access to the means of supporting rural development in poor regions; inadequate access to market where the poor can sell goods and services; low endowment of human capital; destruction of natural resources lending to environmental degradation and reduced productivity; inadequate access to assistance for those living at the margin and those victimised by transitory poverty and lack of participation. That is, the failure to draw the poor into the design of development programmes that affect their lives.

Poverty has many dimensions and may include inadequate access to government utilities and services, environmental issues, poor infrastructure, illiteracy and ignorance, poor health, insecurity, social and political exclusion (National Bureau of Statistics 2010). In the same vein, poverty in a society cannot be linked to economic decline of a country. Indeed, many of the developing societies have witnessed economic growth yet poverty has remained endemic in such societies. Nigeria for instance, according to Toure (2012) had for almost a decade now, been recording consistently high economic growth rate that has not produced commensurate employment opportunities and reduction in poverty among its citizens. Economic growth alone therefore may not guarantee poverty reduction or even elimination in Nigeria. Beyond the issue of economic growth, policies have to be designed in an inclusive manner (involving the targeted people) and faithfully implemented. This is to ensure that people do not conceive the programme as government owned. Apparently, indifferent attitude has also aided the problem of poverty which has for years spawned out of control amidst good poverty oriented policies.

Poverty appears to be a threat to the survival of any political system. Its impact is negatively monumental especially where the political system lacks socio-economic, political and structural wherewithal to addressing poverty incidences. Indeed, Nigerian leaders do not incorporate development agenda capable of improving the wellbeing of ordinary people. Poverty has the tendency towards increasing crime rate, nurturing and recycling disaffection, fuelling instability that would stall development or even collapse the system. In fact, poor governance appears to be the bane of national development in Nigeria. And there seems to be widespread consensus that present poverty crisis in Nigeria is strongly correlated with poor governance. The development crisis in Africa and indeed Nigeria forms major part of the 
debate that necessitated the use of the word "good governance". Good governance model was used by the World Bank as a response to gross mismanagement by African Leaders which seems to be a major cause of development crisis that multiplies poverty incidence. This model is predicated on the assumption that effective and good governance could be a requisite conditionality for surmounting poverty challenges. It tends to reduce poverty and reposition the economy for sustainability.

Good governance is characterized by improvement of public involvement and participation in governance; improved institutional mechanism; adherence to the ideals of the rule of law; enhancement of human rights; and transparency and accountability (Federal Government of Nigeria Report, 2002:111). Good governance therefore also involves evolving a credible method to and indeed operating it towards reducing poverty In fact, the model stresses the notion that the absence or partial existence of the stated principles in any polity sustains poverty and also the fact that the quality of governance of a State plays a vital role in its capacity to deal with poverty related issues which indeed, determines the extent of growth and development.

With the level of poverty in the North East, which equated with many other parts of the country is high, in a country where there are an ever increasing number of energetic youths roaming the streets; the spate of vulnerability is presumably very high. In the reports of National unemployment rates for Nigeria, it showed that the number of unemployed persons which fluctuates between $31.1 \%$ in $2000 ; 31.6 \%$ in $2001 ; 12.6 \%$ in $2002 ; 14.8 \%$ in 2003 ; 13.4\% in 2004; $11.9 \%$ in 2005; also in 2006 it was 13.7\%; in 2007 14.6\%; in 2008 14.9\%; in 2009 19.7\% (National Bureau of Statistics 2009:238), rose from 19.7 in 2009 to $21.1 \%$ in 2010 and 23.9\% in 2011 (The Central Bank of Nigeria Annual Report, 2011 cited in Ladan 2012:7). Yet it is noted that the North East presents a distinctively high record of these poverty and unemployment (see Nwanegbo, Umara and Babagana, 2017).

Searching for a measure out of the precarious poverty situation in Nigeria has been guided by the belief that development really not be achieved with high level of poverty. Seer (1969) in lauding this asserted that the questions to ask about a county's development are;

What has been happening to poverty? What has been happening to unemployment? What has been happening to inequality? If all three of these have declined from high levels, then beyond doubt, this has been a period of development for the country concerned. If one or two of these central problems have been growing worse, especially if all three have, it would be strange to call the result 'development', even if per capita income doubled. This applies of course to the future too. A 'plan' which conveys no targets for reducing poverty, unemployment and inequality can hardly be considered a 'development plan'.

Looking at the various development programmes and plans by the successive administrations in Nigeria, especially those specific on poverty reduction could be helpful in determining the directions of governments' programmes towards development. Perhaps, knowing how they fared would help us to arrive at an informed conclusion on how the CPRP is and tend to achieve its objectives. 


\section{Poverty Alleviation Programmes and Poverty Reduction in Nigeria}

Poverty tends to be described as a global issue though its manifestations and impacts are not evenly felt. Sequel to this, Nations around the world adopt different approaches towards alleviating if not totally eradicating poverty related incidence. In Nigeria, conscious efforts began with the National Accelerated Food Production Programme (NAFPP) in 1974 which was later modified in 1977 to Operation Feed the Nation (OFN) (see Maingwa 2009). This was later followed by "Green Revolution". Subsequently, several other policies towards alleviating poverty in Nigeria were introduced by several other administrations. For instance, to achieve this goal, Babangida's government initiated programmes such as the Directorate for Food, Roads and Rural Infrastructures (DFRRI), Better Life for Rural Women, National Directorate of Employment (NDE), yet, no meaningful development was noticed (Ogunleye 2010).

With the return to civilian governance in 1999, virtually all levels of government introduced different poverty reduction measures. Several states re-introduced free education as part of strategies to reducing high rate of illiteracy. At the National level the Obasanjo led administration created Poverty Alleviation Programme (PAP), which was later in 2001 rechristened National Poverty Eradication Programme (NAPEP). Elumilade, Asaolu and Adereti (2006) observed that;

the new programme (was) structured to integrate four sectoral schemes which include Youth Empowerment Scheme (YES), Rural Infrastructure Development Scheme (RIDS), Social Welfare Service Scheme (SOWESS) and Natural Resources Development and Conservation Scheme (NRDCS).

The Millennium Development Goals (MDGs) as a global agenda also seeks to address issues concerning poverty and hunger, education, gender equality and empowerment of women, child mortality, maternal healthcare, HIV/AIDS, environment and to ensure global partnership for development. The MDGs concurs with the government vision on poverty reduction; hence the establishment of domestic MDGs-like programme tagged National Empowerment and Development Strategy (NEEDS). The programme was further extended to various states and local areas as State Economic Empowerment and Development Strategy (SEEDS) and Local Economic Empowerment and Development Strategy (LEEDS). The administration of Umaru Musa Yar Adua in 2007 proposed a seven-point agenda which includes poverty alleviation through wealth creation. These laudable programmes seem unable to abate the scourge of poverty. Indeed, while many scholars have argued that these programmes are ineffectual, Nwanegbo and Odigbo (2013) noted that;

the ineffectiveness of these programmes is not unconnected to the dubious character of the Nigerian State. The unchecked balkanization and mutilation of democratic principles and practices; and the flaccidity of established institutions of the state aid persistent multiplicity of poverty incidence amidst plenty and well articulated policies. 
In the opinion of the Federal Government, "all failed to meet their objectives largely due to political instability and minimal participation by stakeholders, particularly the poor communities, in the design, management, implementation and evaluation of the intervention" (Federal Government of Nigeria Report: 2000:1). In a specific analysis, Obadan (2001), outlined number of factors that have contributed to the failure of these past poverty-related programmes and efforts. For him, some of them are that:

(1) lack of targeting mechanisms for the poor and the fact that most of the programmes do not focus directly on the poor.

(2) Political and policy instability have resulted in frequent policy changes and inconsistent implementation which in turn have prevented continuous progress.

(3) Inadequate coordination of the various programmes has resulted in each institution carrying out its own activities with resultant duplication of effort and inefficient use of limited resources. Overlapping functions ultimately led to institutional rivalry and conflicts.

(4) Severe budgetary, management and governance problems have afflicted most of the programmes, resulting in facilities not being completed, broken down and abandoned, unstaffed and equipped.

(5) Lack of accountability and transparency thereby making the programmes to serve as conduit pipes for draining national resources.

(6) Over-extended scope of activities of most institutions, resulting in resources being spread too thinly on too many activities. Examples are DFRRI and Better Life Programmes which covered almost every sector and overlapped with many other existing programmes.

(7) Inappropriate programme design reflecting lack of involvement of beneficiaries in the formulation and implementation of programmes. Consequently, beneficiaries were not motivated to identify themselves sufficiently with the successful implementation of the programmes.

(8) Absence of target setting for Ministries, Agencies and Programmes.

(9) Absence of effective collaboration and complementation among the three tiers of government.

(10) Absence of agreed poverty reduction agenda that can be used by all concerned Federal Government, State Governments, Local Governments, NGOs, and the International Donor Community.

(11) Most of the programmes lacked mechanisms for their sustainability.

Looking at the above reasons, one thing appear to be a common factor among many of the technical factor and it is that the programmes appear not to come from the beneficiaries and therefore were not sincerely addressing their problems. That is what the Community-Based 
Poverty Reduction Programme (CPRP) was designed to overcome.

\section{The Community-Based Poverty Reduction Project}

The Community-based Poverty Reduction Projects is one of the most recently adopted mechanisms for channelling development assistance to many parts of the world. Generally, the strategy directly involves beneficiaries in the design and management of the programme. It was originally coined by The World Bank to refer to projects where communities have direct control over key project decisions as well as the management of investment. It is viewed as a poverty reduction mechanism which can enhance sustainability, improve efficiency and effectiveness, allow poverty reduction effects to be taken to scale, make development inclusive, empower poor people, build social capital and strengthen governance, complement market and public sectors among others (Mansuri and Rao, 2003).

Torjman's (1998) sees CPRP as been more than mere provision of basic services to the poor. The concept seeks to integrate and address both economic and social problems which government and NGOs usually address and incorporates methods that are practiced by the private sector. O'Regan and Genway (1993) argue that the community approaches to poverty reduction seek to empower local organizations and individuals with enabling environment for active participation to achieve self-reliance and enduring results. This is to engage disadvantaged communities to participate in governance of local organizations and human resources development. Nares (1998) in Torjman (1998) also noted that the community initiatives build on new skills and ideas recognize hard work, creativity as well as provide employment opportunities and build community assets.

Looking at the research supported reasons for the failure of poverty reduction projects in Nigeria, with the support of International agencies, the Federal and State Governments have adopted and implemented Community- Driven Development (CDD) interventions, as pilots in six selected poorest states and communities: the Community-based Poverty Reduction Projects (CPRP), the Local Empowerment and Environment Management Project (LEEMP) and FADAMA supported by the World Bank and AFDB in 2001(World Bank, 2008).

The main objective of the CPRP was to improve access of the poor to social and economic infrastructure and increase the availability and management of development resources at the community level (Babagana, 2002). The CPRP had two components. Component 1 was handled by the Poverty Alleviation Unit (PAU) of the National Planning Commission on behalf of the Federal government, in charge of: Policy Coordination, Capacity Building, Poverty Monitoring and Impact Assessment. Component 11 was handled by State Agencies on behalf of the State governments.

Since the CPRP has the explicit objective of reversing existing power relations as it creates agency and voice of the poor thus allowing the poor to have control over development assistance (Mansuri and Rao, 2003), it allows development funds to be more responsive to governments and the poor for better targeting, delivery of public goods and services, maintenance of community assets, informed and involved citizens to undertake self-initiated development activity. 
The Quebec experience of the Community-Based Poverty Reduction Project which began since early 1960s brought about reconciliation between individual and collective welfare, development of human potential, self-determination, active participation, decision making and social inclusiveness which are key goals to development (Ninacs, 2003). The Community-Based Poverty Reduction intervention is shown to catalyze holistic development and poverty reduction between 1996 - 2009, to a total project cost of $\$ 20$ million ( $\$ 10$ million by the UNDP, $9.3 \mathrm{~m}$ by World Bank and $0.7 \mathrm{~m}$ others). The Social Funds mechanism of the CPRP has been tested to be successful for poverty reduction in some African Countries including Egypt, The Gambia, Ghana, Uganda, Tanzania and Zambia (FGN Appraisal Report:2000: 10).

Despite recorded achievements of the CPRP, Mansuri and Rao (2003) raised challenges of elite capture for greater influence in decision making, especially when the mandatory community funding contributions are considered. Secondly, the CPRP crucially depend on Institutional assistance for funding, from external and internal sources. These important aspects therefore depend on what they termed as "upward commitment" of the institutions and the facilitating agencies as well as "downward accountability "from the community leaders to avoid a "supply-driven, demand-driven development.

\section{Theoretical Issues}

Discourses about poverty have a lot to do with availability and affordability of the basic needs by the people. The extents at which individual members of the society can afford to access their basic determine the calculable number of persons in poverty and those existing above poverty level. That brings the Basic Needs theory in focus in this discourse.

The Basic needs theorist like Abraham Maslow (1943) examined basic needs from an individual's physiological needs perspective while Streeten, Burki, Ul Haq, Hicks, Stewart (1981) were concerned with meeting the basic consumption needs of the entire population. Their approach sought to place the basic needs objectives of the poor at the centre of all development process. This theory posits that the provision of basic needs aims to remove mass deprivation, a crucial component of development and human resources, and has a trending acceptance among National, International communities and Donors who maintain that the primary objective of any development should be meeting the basic human needs of the majority before the less essential needs of the few are met. The basic needs approach command enormous organizing and integrating power intellectually and politically. Experts opined that a selective targeted approach sharply focused on basic needs and supported by international community is in principle capable of eradicating some of the worst aspects of poverty fairly and quickly.

By focusing on the basic needs of the citizens of Yobe state in terms of provision of basic social amenities, this study contends that the CPRP has greater potentials to deliver basic needs infrastructure faster and creates more organized and integrated human potentials to realize goals and aspirations for subsequent human progress. Provision of basic human needs remain the basic function of all economic activity (Todaro and Smith, 2003); after all, investments in human resources can increase productivity, reduce poverty and achieve 
sustainable development.

\section{Method of Study}

The study was on the impact of CPRP in Yobe State, one of the six (6) selected states for initial application of CPRP by the Nigeria state. Yobe state was created in 1991 and has seventeen (17) Local Government Areas and an estimated population of 2.5 Million (see NPC, census report, 2006). A state endowed with diverse economic potentials, ranging from Chemical and Mineral deposits, Agricultural products, where a variety of Cereals and Livestock production are done in large quantity, with over 80 percent of the population depending on subsistence agriculture, fishing and Livestock for livelihood (Yobe State Diary, 2009) and having a maternal mortality rate with a staggering record of 1,549 death per 100 , 000 live birth and still rising, where the national statistic is 630 deaths per 100,000 live births with some states in the East are maintaining records as low as 165 (see UNDP, 2013).

The study employed the survey method to get information and materials from Two Hundred and Thirty Nine (239) respondents to assess the benefit of projects under the CPRP in three (3) Local Government Areas spread across the three (3) Senatorial Districts in the state. Data was collected through primary and secondary sources, using questionnaires, Focus Group Discussion (FGD) and from existing documents. Inferences were drawn from them to determine the benefits derived from the CPRP. The population of the study consist of respondents from Fika, Damaturu and Yunusari Local Governments. Descriptive and inferential statistics tools used were simple percentage of the data collated with Likert scaled questionnaires calculated from the table representing the reports and Analysis of variance (ANOVA) to analyse data.

For clarity sake, the distribution of the questionnaires was based on the availability of CPRP projects in the selected study area. Looking at the table 6 in the appendix, of the 239 respondents, 39 (16.3\%) were from Damaturu local government, 50 (21.3\%) from Fika and $150(62.4 \%)$ from Yunusari. More responses came from Yunusari Local Government because the number of projects executed in the local government ( 95 community projects) is more than what is in the other selected local governments. While Damaturu local government executed 64 micro projects, Fika with had 26 projects. Also, of all the respondents, 162 $(67.8 \%)$ were male while $77(32.2 \%)$ were females. Participation in most public work is known to be dominated by the male gender in this part of the region, often attributed to the norm; a trend which the YBAPR explained during the interview would be addressed in subsequent CPRP intervention to ensure adequate spread of the benefits of the poverty intervention by all. More especially as poverty is also known to be pronounced among the female gender.

Again, in the of age distribution, 15 - 20 constituted 14 (5.9\%), 21 - 30 has 85 (35.6\%), 31 40 has 87 (36.4\%), and $41-50$ has $48(21.1 \%)$ while 51and above has $5(2.1 \%)$. This result shows that most of the respondents fall within the more actively productive age of the second, third and fourth categories i.e.21 - 50, mostly represented by youths. $21(12.1 \%)$ respondents were single, $195(81.6 \%)$ were married, while $15(6.3 \%)$ are widowed. In the educational qualification of the respondents, 61 (25.5\%) had no formal education, 77 (32.2\%) 
had only Qur'anic education, $11(4.6 \%)$ attended primary school, 15 (6.3\%) attained secondary school level, while $75(31.4 \%)$ got to Tertiary education level. This indicates that while most of the respondents had no formal education at all, almost all had Qu'anic education which is not adequately recognized as a highly considered qualification for a well-paid job in Nigeria, a situation inherited from the colonial system of administration. Poverty is thus present among most of these respondents, as their sources of income is limited to only their skills, which may not likely be as stable and sustainable as that of a civil servant with an even low but regular pay. Only $31.4 \%$ respondents had tertiary education that is made up of mostly by civil servants working in Damaturu.

In the occupation, $52(21.8 \%)$ of the respondents were civil servants, $17(7.1 \%)$ represented Business/traders, $1(0.4 \%)$ skilled workers, 105 (43.9\%) were Farmers and/ or herdsmen, 8 $(3.3 \%)$ were unskilled workers, while $56(23.4 \%)$ were unemployed. From these results, only a mere $21.8 \%$ had stable source of income as salaried workers, the rest of the $78.2 \%$ respondents either had no stable source of income or relied mostly on farming/herding and other unstable and unsustainable sources of income which indicate the likelihood of being in poverty for the majority of them.

\section{Data Presentation and Analysis: CPRP, Micro-Projects and Poverty Reduction in}

\section{Yobe State}

The objective guiding this discourse is to determine if CPRP intervention did improve access to social and economic infrastructure and increase the availability and management of development resources at the community level. To achieve objective assessment of that issue, the paper relied on the analysis of the 239 questionnaires distributed to people from the selected Local Government Areas. In the responses to the question, we grouped the data into --- parts. This first part looked at the general opinion of the respondents on the benefits of the projects executed under CPRP on poverty reduction and community development. Determining this, we have to establish the existing projects so as to decipher between what was from what came with CPRP.

Table 1. Project that existed Before CPRP

\begin{tabular}{l|l|l|l}
\hline Variables; & Frequency & Percent & Cumulative Percentage \\
\hline \multicolumn{1}{c|}{ Health } & & & \\
\hline Existed & 37 & 15.5 & 15.5 \\
\hline Not Existed & 202 & 84.5 & 100.0 \\
\hline Total & $\mathbf{2 3 9}$ & $\mathbf{1 0 0 . 0}$ & \\
\hline Education & & & \\
\hline Existed & 35 & 14.6 & 14.6 \\
\hline Not Existed & 204 & 85.4 & 100.0 \\
\hline Total & $\mathbf{2 3 9}$ & $\mathbf{1 0 0 . 0}$ & \\
\hline Water & & & 15.5 \\
\hline Exited & 37 & 15.5 & 100.0 \\
\hline Not Existed & 202 & 84.5 & \\
\hline Total & $\mathbf{2 3 9}$ & $\mathbf{1 0 0 . 0}$ & \\
\hline Market infrastructure & & & 6.3 \\
\hline Existed & 15 & 6.3 & 100.0 \\
\hline Not Existed & 224 & 93.7 &
\end{tabular}




\begin{tabular}{l|l|l|l}
\hline Total & $\mathbf{2 3 9}$ & $\mathbf{1 0 0 . 0}$ & \\
\hline Rural Electricity & & & \\
\hline Existed & 15 & 6.3 & 6.3 \\
\hline Not Existed & 224 & 93.7 & 100.0 \\
\hline Total & $\mathbf{2 3 9}$ & $\mathbf{1 0 0 . 0}$ & \\
\hline Feeder Road & & & 1.3 \\
\hline Existed & 3 & 1.3 & 100.0 \\
\hline Not Existed & 236 & 98.7 & \\
\hline Total & $\mathbf{2 3 9}$ & $\mathbf{1 0 0 . 0}$ & \\
\hline Ecological Control & & & 4.6 \\
\hline Existed & 11 & 4.6 & 100.0 \\
\hline Not Existed & 228 & 95.4 & \\
\hline Total & $\mathbf{2 3 9}$ & $\mathbf{1 0 0 . 0}$ & \\
\hline Skill Acquisition & & & 5.0 \\
\hline Existed & 12 & 5.0 & 100.0 \\
\hline Not Existed & 227 & 95.0 & \\
\hline Total & $\mathbf{2 3 9}$ & $\mathbf{1 0 0 . 0}$ & \\
\hline Agriculture & & & .4 \\
\hline Existed & 1 & .4 & 100.0 \\
\hline Not Existed & 238 & 99.6 & \\
\hline Total & $\mathbf{2 3 9}$ & $\mathbf{1 0 0 . 0}$ &
\end{tabular}

Source: Field work, 2012

Tables 1 (above) and 2 (below) represent a comparison of Projects that existed before and after the introduction of CPRP respectively. This is to have a picture of the extent of the execution of the CPRP intervention in the study areas. For all the basic infrastructure needs (micro-projects) enumerated above, respondents who admitted that the micro-projects existed in their communities before the introduction of the CPRP intervention are not more than a mere $15.5 \%$. As such virtually all the micro-projects were said not to exist as the average of about $90 \%$ of the respondents admitted that the micro-projects did not exist in their respective communities. To be objective however, and as was revealed during focus group discussion and observed in this study, some of the micro projects have existed in some of these communities, however, due to possible deplorable condition or lack of functionality of these basic services as at the time of the study, respondents viewed such as non-existent. Nonetheless, this result shows that even in the semi-urban area of Damaturu the state capital, the provision of basic infrastructure needs is not sufficient, let alone in most parts of the rural areas of Yobe State. Poverty has therefore continued to increase, while existing facilities were grossly inadequate.

Table 2. Project that existed After CPRP

\begin{tabular}{l|l|l|l}
\hline Variables & Frequency & Percent & Cumulative Percent \\
\hline Health & & & \\
\hline Existed & 51 & 21.3 & 21.3 \\
\hline Not Existed & 188 & 78.7 & 100.0 \\
\hline Total & $\mathbf{2 3 9}$ & $\mathbf{1 0 0 . 0}$ & \\
\hline Education & Frequency & Percent & Cumulative Percent \\
\hline Existed & 85 & 35.6 & 35.6 \\
\hline Not Existed & 154 & 64.4 & 100.0 \\
\hline
\end{tabular}




\begin{tabular}{|c|c|c|c|}
\hline Total & 239 & 100.0 & \\
\hline Water & Frequency & Percent & Cumulative Percent \\
\hline Existed & 218 & 91.2 & 91.2 \\
\hline Not Existed & 21 & 8.8 & 100.0 \\
\hline Total & 239 & 100.0 & \\
\hline Market infrastructure & Frequency & Percent & Cumulative Percent \\
\hline Existed & 25 & 10.5 & 10.5 \\
\hline Not Existed & 214 & 89.5 & 100.0 \\
\hline Total & 239 & 100.0 & \\
\hline Rural Electrification & Frequency & Percent & Cumulative Percent \\
\hline Existed & 38 & 15.9 & 15.9 \\
\hline Not Existed & 201 & 84.1 & 100.0 \\
\hline Total & 239 & 100.0 & \\
\hline Feeder Road & Frequency & Percent & Cumulative Percent \\
\hline Existed & 11 & 4.6 & 4.6 \\
\hline Not Existed & 228 & 95.4 & 100.0 \\
\hline Total & 239 & 100.0 & \\
\hline Ecological & Frequency & Percent & Cumulative Percent \\
\hline Existed & 10 & 4.2 & 4.2 \\
\hline Not Existed & 229 & 95.8 & 100.0 \\
\hline Total & 239 & 100.0 & \\
\hline Skill Acquisition & Frequency & Percent & Cumulative Percent \\
\hline Existed & 2 & .8 & .8 \\
\hline Not Existed & 237 & 99.2 & 100.0 \\
\hline Total & 239 & 100.0 & \\
\hline Agriculture & Frequency & Percent & Cumulative Percent \\
\hline Existed & 6 & 1.2 & 1.2 \\
\hline Not Existed & 233 & 98.8 & 100.0 \\
\hline Total & 239 & 100.0 & \\
\hline
\end{tabular}

Source: Field work, 2012

Table 2 shows that there is a high increase in the provision of some micro-projects after the introduction of the CPRP particularly the provision of water, which rose from mere $15.5 \%$ to 91.2\%. This is more so in Yunusari local government area where water supply project accounted for 84 out of the 95 micro-projects executed. Moreover, the overall sectoral distribution of micro-projects revealed that water supply accounted for 511 out of the 838 micro-projects executed for the whole CPRP intervention projects, gulfing the sum of N646,145,602.31 out of the total of about N1,712,883,881.56, expended for all the nine (9) sector projects (CSDP Launching, 2009). This shows the extent of the utter neglect and deprivation experienced by the citizens of Yobe State from lack of critical basic needs such as water which has undoubtedly contributed immensely to the precariousness, prevalence and persistence of poverty in Yobe State. After all, 'Water' as a popular saying goes 'is life'. The 
pathetic lack of water needs no further explanation as also lack in other basic needs in Yobe State.

There is also a slight increase in the provision of Health facilities from $15.5 \%$ to $21.3 \%$. The provision of Education also rose from $14.6 \%$ to $35.6 \%$, Rural Electrification $6.3 \%$ to $15.9 \%$, Feeder Road 1.3 to $4.6 \%$ and Market infrastructure $6.3 \%$ to $10.5 \%$, while Agriculture which is the main subsistent occupation for over $70 \%$ of the population of people in Yobe State shifted from $.4 \%$ to $1.2 \%$ level of existence in terms of facilities that aided bumper food production in Yobe State. It may be observed that even with the increase in education infrastructure ( $21 \%$ increase), $64.4 \%$ of respondents i.e. more than half of respondents pointed out that the provision of education infrastructure does not exist even after the CPRP intervention. No wonder, the Human Development Index for Yobe State rated literacy level as low. Ngama, Bunu and Saidu (2008) confirmed the acute shortages of education infrastructure, facilities and teachers at all levels due to continued neglect of policy frameworks within the sector, gender issues and socio-cultural beliefs and practices. The slight increase in the existence of all the micro-projects, except water, which is significant, means that the provision of the micro-projects is still inadequate even after the CPRP intervention.

Table 3. Respondents rating of the provisions of projects before CPRP

\begin{tabular}{llll}
\hline & Frequency & Percent & Cumulative Percent \\
\hline Adequate & 20 & 8.4 & 8.4 \\
Fairly Adequate & 31 & 13.0 & 21.3 \\
Inadequate & 53 & 22.2 & 43.5 \\
Non - existing & 133 & 55.6 & 99.2 \\
Don't Know & 2 & .8 & 100.0 \\
Total & 239 & 100.0 & \\
\hline
\end{tabular}

Source: Field work, 2012

Table 3 revealed that over half of respondents, representing 133(55.6\%) hold that the provision of projects in their communities prior to CPRP intervention was non-existing, while $53(22.2 \%)$ said provision of the projects was inadequate. Only a negligible $20(8.4 \%)$ of respondents accepted the provision of projects as adequate. Judging from the results obtained in this table it could be deduced that the provision of projects in the communities before the CPRP intervention was rated poorly by the respondents, to say the least.

Table 4. Respondents rating of provision of projects after the Introduction of CPRP

\begin{tabular}{llll}
\hline Variable & Frequency & Percent & Cumulative Percent \\
\hline Adequate & 80 & 33.5 & 33.5 \\
Fairly Adequate & 141 & 59.0 & 92.5 \\
Inadequate & 9 & 3.8 & 96.2 \\
Non - existing & 2 & .8 & 97.1 \\
Don't Know & 7 & 2.9 & 100.0 \\
Total & 239 & 100.0 & \\
\hline
\end{tabular}

Source: Field work, 2012

Table 4 indicates that even after the CPRP intervention, most respondents rated the provision as fairly adequate, representing $141(59.0 \%)$. Followed by respondents $80(33.5 \%)$ who rated 
the provisions of projects in their community as adequate after the CPRP. The rest, $9(3.8 \%)$, $7(2.9 \%)$ and $2(0.8 \%)$ respondents said it was inadequate, don't know, and non-existing respectively. Observing from the results obtained, it could be seen clearly that the provision of projects in the communities after the introduction of the CPRP was rated as just fairly adequate. This shows that much still needs to be done towards the provision of infrastructure to cater for basic human needs in Yobe State. Besides, tackling poverty of this magnitude there is a need for a strategy that will affect all the spheres of basic needs simultaneously as often suggested by development experts.

Table 5. Benefits derived from the projects by community members

\begin{tabular}{llll}
\hline Variable & Frequency & Percent & Cumulative Percent \\
\hline Highly Satisfactory & 77 & 32.2 & 32.2 \\
Satisfactory & 95 & 39.7 & 72.0 \\
Fairly Satisfactory & 67 & 28.1 & 100.0 \\
Not Satisfactory & - & - & - \\
Don't Know & - & - & - \\
\hline Total & 239 & 100.0 & \\
\hline
\end{tabular}

Source: Field work, 2012

On the benefits derived from the projects, Table 5 shows that $95(39.7 \%)$ of respondents were satisfied, closely followed by 77(32.2\%) who were highly satisfied and 67(28.1\%) who felt fairly satisfactory with benefits derived. This optimistic wave of satisfaction clearly indicates that the communities welcome the CPRP intervention, as they expressed hope that the intervention will be a continuous one. However, this is by no means an assertion that the provision of basic amenities is enough to reduce poverty at a significant level at this stage.

The CPRP intervention sought to improve access to social and economic infrastructure and increase the availability and management of development resources at the community level. To this end, the hypothesis that there is no significant difference among the respondents on the relationship between poverty reduction and the execution of the CPRP micro-projects in the selected benefiting communities is tested below using ANOVA.

The calculated F Statistics with critical (table) values using the within df (12) and the B/W df (2) at the 0.05 level of significance is 3.88 . The calculated value of 0.75 is less than the critical value $3.88 \mathrm{Df}$ at 0.5 level of significance. Therefore the null hypothesis is accepted with the conclusion that there is no significant difference in the relationship between the execution of micro-projects and poverty reduction among the selected benefiting communities. In essence, the execution of micro-projects has not reduced poverty among the selected benefiting communities. Although the result may appear to be at variance with ratings by respondents, the statistical test showed that such variations are insignificant to warrant the conclusion of concrete poverty reduction. This may be attributed to the fact that the study has not only indicated the inadequacy and lack of widespread distribution of projects in all the sectors of the CPRP, but that participation in the CPRP has not increased the communities capacity to reduce their poverty. Thus the execution of the micro-projects has no significant impact on poverty reduction in the selected area of study. 


\section{Major Findings of the Study}

The following are major findings from the field survey, focus group discussion and interview of officials of the Facilitating agency. The study revealed that a total of 185 micro-projects in social amenities sectors including Health, Education, and Water etc were executed by the various selected benefiting communities.

First, the study showed that there was lack or deplorable conditions of most of the micro-projects in the selected benefiting communities before the introduction of the CPRP. Invariably the provision of most basic needs infrastructure in the selected communities is considered to be grossly inadequate. After the introduction of the CPRP however, there was slight increase in the provision of the micro-projects. Nonetheless, the availability of the micro-projects is still not adequate enough to cater for the basic needs requirement of the communities.

Second, the provision of the micro-projects had reduced poverty but with no appreciable result for concrete poverty reduction among the respondents or the communities at large. However, most respondents acknowledged the fact that even though the CPRP did not actually reduce their poverty in terms of individual income, it had certainly brought relief to some of their daily worries, particularly the problem of water for both human and animal consumption in their various communities.

Third, the study showed that communities have benefited from the provision of the executed micro-projects. The focus group discussion held and interview with the YBAPR officials showed that respondents also benefited from their involvement in the CPRP process through capacity training they had undergone. This provided communities with a strong sense of relevance and shared responsibility, especially in relation to the mandatory $10 \%$ contribution of the cost of each micro-project executed in their communities.

\section{Summary and Conclusion}

Current approaches to poverty reduction measures prepare multi-stakeholder strategy to tackle poverty problems. The CPRP in particular has identified the need for the provision of the basic needs infrastructure as the first step to take towards tackling poverty problems with adequate involvement and active participation of the poor benefiting communities in all decision making process and implementation of projects provided to alleviate poverty problems.

In this study, an attempt was made to assess the benefits derived from the CPRP to reduce poverty in Yunusari, Damaturu and Fika Local government areas in Yobe State. The concept of the CPRP is aimed at directly involving the benefiting communities in the intervention process. The study examined causes of poverty, poverty alleviation programmes in Nigeria and the concept of the CPRP among others. The study revealed that the concept for which the CPRP was adopted has been achieved in Yobe State where a total of 185 micro-projects were executed in the 3 areas of study and 838 projects in the 17 local government areas from 2002 to 2009. However, it showed that the provision of the CPRP micro-projects in most of the sectors was neither adequate nor widespread enough to reduce poverty in the selected area of 
study. In terms of benefits derived by the communities however, the micro-projects have ameliorated their daily problems particularly the success of the provision of water supply for human and animal consumption. This may be attributed to the sheer lack of availability or functionality of the basic needs infrastructure in these communities before the CPRP intervention.

Since lack of basic needs infrastructure is widespread and multifaceted, there is the need for Yobe State Government to reproduce the CPRP strategy to tackle poverty problem holistically in the State by creating enabling political environment for stakeholders to function effectively and benefit maximally. In order to translate the CPRP intervention for concrete poverty reduction among poor communities, efforts should be sustained to avoid ad-hoc solutions to poverty problems.

\section{References}

Aderonmu, J. A. (2010). Local Government and Rural Poverty Eradication in Rural Nigeria, in Canadian Social Science, 6(5), 200-208. Available at: http://www.CScanada.org

Aluko, M. A. O. (2003). Strategies for Poverty Reduction in Nigeria. Journal of Social Science, 7(4). https://doi.org/10.1080/09718923.2003.11892388

Babagana, A. G. (2010). Yobe State Agency for Community and Social Development, An Update of it's Activities. A paper presented by the General Manager with the Peer Review Team of the Governor's Forum, in Wawa Hall, Government House, Damaturu.

Babagana, A. G. (2002). The Official State Launching of the Yobe State Agency for Poverty Reduction. Address by the General Manager, Yobe State Agency for Poverty Reduction, on the occasion of the official State launching of the activities of the Agency, Damaturu.

Human Development Report (Nigeria) (2004). "HIV and AIDS": A Challenge to Sustainable Human Development.

Ibrahim, A. B. (2002). The Official State Launching of Yobe State Agency For Poverty Reduction. Address by the Executive Governor of Yobe State, on the occasion of the official State launching of the activities of the Yobe State Agency for Poverty Reduction (YBAPR), Damaturu.

Kankwenda, M., Gregoire, L., Legros, H., \& Ouedraogo, H. (2000). Poverty Eradication: Where Stand Africa, Economica Ltd, London.

Kiss, A. (2004). Trends in Ecology and Evolution, 19(5), @ http://www.ecotourism.org/index2.php.

Kpakol, M. L. (2006), Selected Speeches and Presentations of the National Coordinator, NAPEP, Published by National Poverty Eradication Programme, Abuja.

Maduagwu, A. (2000). Alleviating Poverty in Nigeria; In Africa Economic Analysis; Available at: http://www.afbis.com

Maiangwa, J. S. (2009). An Overview of Pseudo-Therapic Approaches to Poverty in Nigeria: 
The Citizens and the State in Africa Journal of Political Science and International Relations, 3(9). Available at: http://www.academicjournals.org/AJPSIR

Mansuri, G., \& Rao, V. (2003). Community-Based ( and Driven) Development: A Critical Review" Development Research Group, The World Bank@ @ttp://www.wds.worldbank.org.

Nagabasku, A. B. (2009). Yobe State Agency for Community and Social Development Launching, Welcome Address by the Chairman Yobe State Agency for Community and Social Development, on the occasion of the official State launching of the activities of the Agency, Damaturu'

NAPEP. (2007). NAPEP Today: Apex Agency for Poverty Eradication. Published by National Poverty Eradication; Nigeria, Abuja.

National Planning Commission (2004) NEEDS Nigeria: Meeting Every One's Needs. National Economic Empowerment and Development Strategy, Abuja.

Ngama, L. Y., Bunu, Z., \& Saidu, S. (Eds.). (2009). Proceedings of the Yobe State Economic Summit 2008, Spectrum Books Limited, Nigeria, Ibadan.

Ninacs, W. (2003). Community-based Poverty Reduction: The Quebec Experience Caledon Institute of Social Policy, Ottawa, Ontario, Canada @ http://www.caledoninst.org.

Obadan, M. I. (1996). Poverty in Nigeria: Characteristics Alleviation Strategies and Programmes in NCEMA Policy Analysis Series 2(2); Available at: htpp://www.holleafrica.com

Obadan, M. I. (2003). Poverty Reduction in Nigeria: The way forward in Obadan M, A.A. Fajingbesi and E.O.Uga,(eds) Integrating Poverty Alleviation Strategies into Plans and Programmes in Nigeria in CBN Economic and Financial Review, 39(4). Available at: http://www.cenbank.org/Publications/efr/RD/2002/efr; 3(4-3).

Ogwumike, F. O. (2002). An Appraisal of Poverty Reduction Strategies in Nigeria. CBN Economic and Financial Review, 39(4). Available at: http://www.cenbank.org/out/publications/efr/RD/2002/efr 39 (4-4); S. Torjman,(1998), "Social Programs Play a Crucial Role in Supplementing Low earnings and Providing free or subsidized Services and Support" Caledon Institute of Social Policy, Ottawa @ http://www.Caledoninst.org/publications/PDF/1-89.

Pate, U., \& Garba, A. (2010). Poverty Mapping and Profiling; A Preliminary Report on Yobe State, Damaturu.

Rodney, W. (1972) How Europe Underdeveloped Africa. Dar-es- Salaam, Tanzania Publishing House

Streeten, P., Burki, S. J., Ul Haq, M., Hicks, N., \& Stewart, F. (1981) First Things First: Meeting the Basic Needs of the Developing Countries. The World Bank, Oxford University.

The World Bank and Federal Republic of Nigeria. (2000). Appraisal Report: Community-based Poverty Reduction Project 


\section{Macrothink}

Journal of Public Administration and Governance

ISSN 2161-7104

2018, Vol. 8, No. 2

The World Bank. (2008) Project Appraisal Document on A Proposed Credit in the amount of SDR 121.5 Million (US \$ 200 Million Equivalent) to the Federal Government of Nigeria for a Community and Social Development Project, Human Development III Country Department AFC2, (41634-NG), Africa Region.

Todaro, M. P., \& Smith, C. S. (2004) Economic Development; Pearson Education, 8th Edition (Singapore) Pte. Ltd. India, Patparganj, Delhi.

Yobe State Agency for Poverty Reduction. (2009). Approved Projects, Damaturu.

Yobe State Government of Nigeria. (2009). The New Era of Transformation; Brief on Yobe State, 2009 Diary, Ministry of Home Affairs, Information and Culture, Damaturu.

\section{Appendix: Personal Data of Respondents}

Table 6. Demographic data of the respondents

\begin{tabular}{|c|c|c|c|}
\hline Local Government Area & Frequency & Percent & $\begin{array}{l}\text { Valid } \\
\text { Percent }\end{array}$ \\
\hline Damaturu & 39 & 16.3 & 16.3 \\
\hline Fika & 50 & 21.3 & 21.3 \\
\hline Yunusari & 150 & 62.4 & 62.4 \\
\hline Total & 239 & 100.0 & 100.0 \\
\hline \multicolumn{4}{|l|}{ Sex of Respondents } \\
\hline Male & 162 & 67.8 & 67.8 \\
\hline Female & 77 & 32.2 & 32.2 \\
\hline Total & 239 & 100.0 & 100.0 \\
\hline \multicolumn{4}{|l|}{ Age of Respondents } \\
\hline $15-20$ & 14 & 5.9 & 5.9 \\
\hline $21-30$ & 85 & 35.6 & 35.6 \\
\hline $31-40$ & 87 & 36.4 & 36.4 \\
\hline $41-50$ & 48 & 20.1 & 20.1 \\
\hline $51 \&$ Above & 5 & 2.1 & 2.1 \\
\hline Total & 239 & 100.0 & 100.0 \\
\hline \multicolumn{4}{|c|}{ Marital Status of Respondents } \\
\hline Single & 29 & 12.1 & 12.1 \\
\hline Married & 195 & 81.6 & 81.6 \\
\hline Widowed & 15 & 6.3 & 6.3 \\
\hline Total & 239 & 100.0 & 100.0 \\
\hline \multicolumn{4}{|c|}{ Educational Qualification of Respondents } \\
\hline No Formal Ed. & 61 & 25.5 & 25.5 \\
\hline Qur'anic Ed. & 77 & 32.2 & 32.2 \\
\hline Primary Sch. & 11 & 4.6 & 4.6 \\
\hline Secondary Sch. & 15 & 6.3 & 6.3 \\
\hline Tertiary Ed. & 75 & 31.4 & 31.4 \\
\hline Total & 239 & 100.0 & 100.0 \\
\hline \multicolumn{4}{|c|}{ Occupation of Respondents } \\
\hline Civil Servant & 52 & 21.8 & 21.8 \\
\hline Business/trader & 17 & 7.1 & 7.1 \\
\hline Skilled & 1 & .4 & .4 \\
\hline Farmer/Shepherd & 105 & 43.9 & 43.9 \\
\hline Unskilled & 8 & 3.3 & 3.3 \\
\hline Unemployed & 56 & 23.4 & 23.4 \\
\hline Total & 239 & 100.0 & 100.0 \\
\hline
\end{tabular}


Source: Field work, 2012 2018, Vol. 8, No. 2

\section{Copyright Disclaimer}

Copyright for this article is retained by the author(s), with first publication rights granted to the journal.

This is an open-access article distributed under the terms and conditions of the Creative Commons Attribution license (http://creativecommons.org/licenses/by/4.0/). 